\title{
KEPENTINGAN POLITIK PENGUASA TERHADAP PENDIDIKAN KEWARGANEGARAAN DI INDONESIA
}

\author{
Oleh \\ Sunarso \\ Jurusan PKnH FISE UNY
}

\begin{abstract}
Abstrak
Kepentingan politik penguasa terhadap Pendidikan Kewarganegaraan di Indonesia dapat dirunut dalam sejarah perkembangan mata pelajaran ini, sejak munculnya dalam sistem pendidikan nasional pada era Orde Lama hingga Orde Reformasi. Mata pelajaran ini muncul pertama kali tahun 1957. Pendidikan Kewarganegaraan mempunyai misi yang khas. Mata pelajaran ini menonjol dengan misinya untuk mewujudkan sikap toleransi, tenggang rasa, memelihara persatuan dan kesatuan, tidak memaksakan pendapat dan lain-lain, yang dirasionalkan demi terciptanya stabilitas nasional sebagai prasyarat bagi kelangsungan pembangunan. Di balik semua itu Pendidikan Kewarganegaraan sesungguhnya telah berfungsi sebagai alat penguasa untuk melanggengkan kekuasaan. Sosok Pendidikan Kewarganegaraan (Civic atau Citizenship) yang demikian memang sering muncul di sejumlah negara, khususnya negara-negara berkembang termasuk Indonesia.
\end{abstract}

\section{Pendahuluan}

Jatuhnya Soeharto dari kekuasaan pada Mei 1998, berikut dengan krisis moneter, ekonomi dan politik, telah mendorong reformasi bukan hanya dalam bidang politik dan ekonomi. Melainkan dalam bidang pendidikan. Reformasi dalam bidang pendidikan pada dasarnya merupakan reposisi dan bahkan rekonstruksi pendidikan secara keseluruhan. Reformasi, reposisi, dan rekonstruksi pendidikan jelas harus melibatkan penilaian kembali secara kritis pencapaian dan masalahmasalah yang dihadapi pendidikan nasional.

Pendidikan nasional menurut banyak kalangan bukan hanya belum berhasil meningkatkan kecerdasan dan ketrampilan anak didik, melainkan gagal dalam membentuk karakter dan kepribadian (nation and character building). Padahal pembentukan karakter dan kepribadian ini sangat penting, bahkan sangat mendesak, karena masih berkelanjutannya berbagai krisis yang melanda bangsa dan negara Indonesia hingga saat ini (Azyumardi Azra, 2006:vi)

Paradigma pendidikan yang dianut pada masa Orde Baru adalah "pendidikan untuk pembangunan", sehingga pendidikan telah diposisikan sedemikian rupa sebagai instrumen pembangunan. Pembangunan Manusia Indonesia Seutuhnya yang 
menjadi jargon Orde Baru dalam kebijakan dan operasionalnya ternyata lebih banyak berpihak dan berorientasi pada pertumbuhan ekonomi. Ironisnya pembangunan yang telah berlangsung selama lebih 30 tahun dan telah "dibayar dengan mahal" lebih-lebih menyangkut social cost yang sifatnya uncalculated, ternyata justru menghasilkan keterpurukan di berbagai bidang. Pengalaman pada masa Orde Baru itu telah memberikan pelajaran "berharga" tentang betapa rapuhnya suatu pembangunan yang hanya menekankan pada aspek phisik-materiil dan kepentingan-kepentingan ekonomi belaka (Muchson, 2004).

Pendidikan Kewarganegaraan mempunyai misi yang lebih khas. Mata pelajaran (mata kuliah) ini menonjol dengan misinya untuk mewujudkan sikap toleransi, tenggang rasa, memelihara persatuan dan kesatuan, tidak memaksakan pendapat dan lain-lain, yang dirasionalkan demi terciptanya stabilitas nasional sebagai prasyarat bagi kelangsungan pembangunan. Di balik semua itu Pendidikan Kewarganegaraan sesungguhnya telah berfungsi sebagai alat penguasa untuk melanggengkan kekuasaan. Sosok Pendidikan Kewarganegaraan (Civic atau Citizenship) yang demikian memang sering muncul di sejumlah negara, khususnya negara-negara berkembang, sesuai dengan laporan penelitian Cogan (1998) yang dikutip oleh Ace Suryadi dan Somantri (2000:1) yang mengatakan:

"Citizenship education has often reflected the interest of those in power in particular society and thus has been a matter of indoctrination and the establishment of ideological hegemony rather than of education".

Kepentingan politik penguasa terhadap Pendidikan Kewarganegaraan di Indonesia dapat dirunut dalam sejarah perkembangan mata pelajaran (mata kuliah) ini, sejak munculnya dalam sistem pendidikan nasional. Mata pelajaran (mata kuliah) ini muncul pertama kali tahun 1957 dengan nama "Kewarganegaraan", yang isinya sebatas tentang hak dan kewajiban warga negara, serta cara-cara memperoleh dan kehilangan status kewarganegaraan. Sebagai tindak lanjut dari Dekrit Presiden 5 Juli 1959, Menteri PP dan K mengeluarkan Surat Keputusan No. 122274/S tanggal 10 Desember 1959 tentang pembentukan panitia penyusunan buku pedoman mengenai kewajiban-kewajiban dan hak-hak warga negara Indonesia dan hal-hal yang menginsyafkan warga negara tentang sebab-sebab sejarah dan tujuan Revolusi Indonesia. Panitia tersebut berhasil menyusun buku Manusia dan Masyarakat Baru 
Indonesia pada tahun 1962 yang menjadi acuan mata pelajaran civics yang telah muncul pada tahun 1961. Buku tersebut berisi tentang Sejarah Pergerakan Rakyat Indonesia; Pancasila; UUD 1945; Demokrasi dan Ekonomi Terpimpin; Konferensi Asia Afrika; Hak dan Kewajiban Warga Negara; Manifesto Politik; dan lampiranlampiran Dekrit Presiden, Pidato Lahirnya Pancasila, Panca Wardana, dan Declaration of Human Rights, serta pidato-pidato Presiden lainnya yang dipaketkan dalam Tujuh Bahan Pokok Indoktirinasi (Tubapi).

Sejak munculnya Orde Baru pada tahun 1966, isi mata pelajaran Civics versi Orde Lama hampir seluruhnya dibuang, karena dianggap sudah tidak sesuai lagi dengan tuntutan yang sedang berkembang. Pada Kurikulum 1968, mata pelajaran ini muncul dengan nama "Kewargaan Negara", yang isinya di samping Pancasila dan UUD1945, adalah Ketetapan-Ketetapan MPRS 1966, 1967, dan 1968, termasuk GBHN, Hak Asasi Manusia, serta beberapa materi yang berspek sejarah, geografi, dan ekonomi. Sesuai dengan manta Ketetapan MPR No. IV/MP/1973, mata pelajaran ini berubah nama menjadi Pendidikan Moral Pancasila (PMP) pada Kurikulum 1975. Dengan ditetapkannya Ketetapan MPR No. II/MPR/1978 tentang P-4, maka terjadilah perkembangan yang cukup substantif mengenai materi mata pelajaran ini, yakni sangat dominannya materi P-4 dalam PMP. Bahkan dalam penjelasan ringkas tentang PMP oleh Depdikbud (1982) dinyatakan bahwa hakikat PMP tidak lain adalah pelaksanaan P-4 melalui jalur pendidikan formal. Hal ini tetapberlangsung hingga berlakunya Kurikulum 1984 maupun Kurikulum 1994, dimana "Pendidikan Moral Pancasila" (PMP) telah berubah nama menjadi “ Pendidikan Pancasila dan Kewarganegaraan" (PPKn). Dalam perkembangannya yang terakhir, materi P-4 secara resmi tidak lagi dipakai dalam Kurikulum Suplemen 1999, apalagi Ketetapan MPR No. II/MPR/1978 tersebut telah dicabut dengan Ketetapan MPR No. XVIII/MPR/1998.

Pada era reformasi ini Pendidikan Kewarganegaraan juga sedang dalam proses reformasi ke arah Pendidikan Kewarganegaraan dengan paradigma baru (New Indonesian Civic Education). Reformasi itu mulai dari aspek yang mendasar, yaitu reorientasi visi dan misi, revitalisasi fungsi atau peranan, hingga restrukturisasi isi kurikulum dan materi pembelajaran. Seiring dengan itu, dalam sistem pendidikan 
nasional juga sedang disosialisasikan pembaharuan kurikulum dengan konsep yang disebut kurikulum berbasis kompetensi.

\section{Tinjauan Umum Tentang Pendidikan Kewarganegaraan}

Secara klasik sering dikemukakan bahwa tujuan Pendidikan Kewarganegaraan di Indonesia adalah untuk membentuk warga negara yang baik (a good citizen). Akan tetapi pengertian warga negara yang baik itu pada masa-masa yang lalu lebih diartikan sesuai dengan tafsir penguasa. Pada masa Orde Lama, warga negara yang baik adalah warga negara yang berjiwa "revolusioner", anti imperialisme, kolonialisme, dan neo kolonialisme. Pada masa Orde Baru, warga negara yang baik adalah warga negara yang Pancasilais, manusia pembangunan dan sebagainya. Sejalan dengan visi Pendidikan Kewarganegaraan era Reformasi, misi mata pelajaran ini adalah meningkatkan kompetensi siswa agar mampu menjadi warga negara yang berperan serta secara aktif dalam sistem pemerintahan negara yang demokratis. Sehubungan dengan itu, Ace Suryadi dan Somardi (2000:5) mengemukakan bahwa Pendidikan Kewarganegaraan memfokuskan pada tiga komponen pengembangan, yaitu (1) civic knowledge, (2) civic skill, dan (3) civic disposition. Inilah pengertian warga negara yang baik, yang diharapkan oleh Pendidikan Kewarganegaraan di Era Reformasi.

Pendidikan Kewarganegaraan di Era Reformasi dituntut merevitalisasi diri agar mampu melaksanakan misi sesuai dengan visinya itu. Hingga saat ini mata pelajaran tersebut seakan tidak memiliki vitalitas, tidak berdaya, dan tidak dapat berfungsi secara baik dalam meningkatkan kompetensi kewarganegaraan.

Dalam penataannya di dalam struktur kurikulum, Belinda Charles dalam Print (1999:133-135), merekomendasikan isi Pendidikan Kewarganegaraan dapat ditata dalam tiga model, yaitu formal Curriculum, Informal Curriculum, Hidden Curriculum. Dengan model formal curriculum, implementasi pembelajarannya dapat menembus berbagai mata pelajaran (cross-curriculum). Dengan model informal curriculum dapat diimplementasikan dalam kegiatan-kegiatan ekstra kurikuler, seperti kepanduan, klub-klub remaja, PMR, kegiatan rekreasi, dan olah raga. Model ini justru efektif dalam pembentukan karakter remaja. Dengan model 
hidden curriculum, seperti misalnya etika, dapat dikembangkan dalam tingkah laku sehari-hari.

\section{Pendidikan Kewarganegaraan sebagai Pendidikan Karakter}

Azyumardi mengklasifikasi penyebab krisis mentalitas, moral, dan karakter mahasiswa di perguruan tinggi yang juga menjadi bagian dari pendidikan nasional. Ada tujuh masalah pokok yang turut menjadi akar krisis mentalitas dan moral di lingkungan perguruan tinggi. Antara lain: arah pendidikan telah kehilangan obyektivitasnya; proses pendewasaan diri tidak berlangsung; proses pendidikan di sekolah dan perguruan tinggi sangat membelenggu siswa dan mahasiswa dan, bahkan juga guru dan dosen; beban kurikulum yang demikian berat, lebih parah lagi, hampir sepenuhnya diorientasikan pada pengembangan ranah kognitif belaka; beberapa mata pelajaran dan matakuliah, termasuk juga pendidikan agama dan pendidikan kewarganegaraan, disampaikan dalam bentuk verbalisme, yang juga disertai dengan rote-memorizing, pada saat yang sama siswa dan mahasiswa dihadapkan kepada nilai-nilai yang sering bertentangan; Siswa dan mahasiswa juga mengalami kesulitan dalam mencari contoh teladan yang baik di lingkungannya (Azyumardi Azra, 2006:xi).

Ketujuh permasalahan tersebut harus dicarikan solusinya. Solusi tidak bisa dilakukan secara adhoc dan parsial. Bahkan dapat dikatakan, pemecahan masalahmasalah besar itu meniscayakan reformasi itu sendiri secara keseluruhan. Karena, masalah-masalah tersebut saling berkaitan.

Persoalan lain yang dihadapi bangsa ini adalah tentang pembentukan masyarakat madani yang sering disebut civil society, terwujudnya masyarakat demokratis, pelaksanaan otonomi daerah, dan terrealisasinya pemerintahan yang bersih melalui jalur pendidikan nasional. Harus diakui upaya untuk mengaktualisasikan demokrasi dan civil society di Indonesia melalui jalur pendidikan kelihatannya masih harus menempuh jalan panjang, terjal, dan berlikuliku.

Oleh karena itu Pendidikan Kewarganegaraan di sekolah dan di perguruan tinggi harus melakukan reorientasi, rekonstruksi kritis, restrukturisasi, dan reposisi, serta berusaha untuk menerapkan paradigma baru. Upaya-upaya itu harus bertujuan 
akhir pembentukan masyarakat Indonesia yang demokratis, bersih, bermoral, dan berakhlak; dan berpegang teguh pada nilai-nilai civility (keadaban). Sekolah harus memenuhi tiga aspek, yaitu pengetahuan, skill, dan membentuk karakter. Center for Civic Education pada tahun 1994 dalam National Standards for Civics and Government. Ketiga komponen pokok tersebut, yaitu civic knowledge, civic skills, dan civic dispositions (Margaret S. Bronson, dkk., 1999:8-25).

Pengetahuan kewarganegaraan (civic knowledge) merupakan meteri substansi yang harus diketahui oleh warga negara. Pada prinsipnya pengetahuan yang harus diketahui oleh warga negara berkaitan dengan hak dan kewajiban sebagai warga negara, pengetahuan tentang struktur dan sistem poitik dan pemerintahan, nilai-nilai universal dalam masyarakat demokratis, cara-cara kerjasama untuk mewujudkan kemajuan bersama, serta hidup berdampingan secara damai dalam masyarakat internasional.

Ketramtpilan kewarganegaraan (civic skills), merupakan ketrampilan yang dikembangkan dari pengetahuan kewarganegaraan, agar [pengetahuan yang diperoleh menjadi sesuatu yang bermakna, karena dapat dimanfaatkan dalam menghadapi masalah-masalah kehidupan berbangsa dan bernegara. Civic skills mencakup intellectual skills (ketrampilan intelektual) dan participation skills (ketrampilan partisipasi).

Karakter kewarganegaraan (civic dispositions), merupakan sifat-sifat yang harus dimiliki setiap warga negara untuk mendukung efektivitas partisipasi politik, berfungsinya sistem politik yang sehat, berkembangnya martabat dan harga diri dan kepentingan umum.

Civic Education (Pendidikan Kewarganegaraan) memfokuskan pada demokrasi politik atau demokrasi sebagai sebuah sistem politik. Karena Civic Education sebagai bagian dari sosialisasi politik berfungsi sebagai pemelihara dan pengembang sistem politik yang ideal yaitu demokrasi. Dalam demokrasi konstitusional, civic education yang efektif adalah suatu keharusan. Karena kemampuan untuk berpartisipasi dalam masyarakat demokratis, berfikir secara kritis, dan bertindak secara sadar dalam dunia yang plural, memerlukan empati yang memungkinkan kita mendengar dan mengakomodasi pihak lain semuanya itu memerlukan kemampuan yang memadai. 
Dikutip dari Buku Ilmu Pend hl 693.......

\section{Pendidikan Kewarganegaraan Pada Era Orde Lama}

Perjalanan sejarah Bangsa Indonesia menunjukkan bahwa pendidikan formal dijadikan sarana untuk mempersiapkan warganegara yang sesuai dengan cita-cita nasional. Upaya itu nampak dari lahirnya berbagai nama untuk Pendidikan Kewarganegaraan (PKn) yang sering berganti-ganti sejalan dengan perkembangan dan pasang surutnya perjalanan politik Bangsa Indonesia. Hal itu ditunjukkan dengan lahirnya berbagai kebijakan di bidang pendidikan khususnya tentang PKn sebagai tindak lanjut dari Dekrit Presiden 1959 untuk kembali ke UUD 1945, diantaranya dengan instruksi pembaharuan buku-buku di universitas-universitas.

Pemerintah dalam hal ini, Departemen $\mathrm{P}$ dan $\mathrm{K}$ mengeluarkan surat keputusan No. 122274/S, tanggal 10 Desember 1959, membentuk panitia yang terdiri dari 7 orang. Tugas panitia tersebut membuat buku pedoman mengenai kewajiban-kewajiban dan hak-hak warganegara Indonesia disertai hal-hal yang akan menginsyafkan mereka tentang sebab-sebab sejarah dan tujuan Revolusi Kemerdekaan kita (Supardo, dkk, 1962). Panitia tersebut berhasil menyusun buku "Manusia dan Masyarakat Baru Indonesia" pada tahun 1962. Menurut para penulisnya (Supardo, dkk.), buku ini dapat disebut dengan istilah Jerman "Staatsburgerkunde", dengan istilah Inggris "Civics" atau dengan istilah Indonesia “Kewarganegaraan”. Akan tetapi oleh karena isi buku ini agak luas maka, nama "Manusia dan Masyarakat Baru Indonesia" agaknya lebih tepat.

Buku pedoman PKn tersebut berisi (1) Sejarah pergerakan/perjuangan rakyat Indonesia, (2) Pancasila, (3) UUD 1945, (4) Demokrasi dan Ekonomi Terpimpin, (5) Konferensi Asia Afrika, (6) Kewajiban dan hak warganegara, (7) Manifesto Politik, (8) Laksana Malaikat dan Lampiran-lampiran tentang Dekrit Presiden, Lahirnya Pancasila, Pidato Presiden Soekarno, Declaration of Human Rights dan Panca wardhana (lima perkembangan). Pada dasarnya bahan pelajaran kewarganegaraan tersebut telah digunakan sejak 1959 sampai dengan pecahnya Pemberontakan Partai Komunis Indonesia (PKI) pada tanggal 30 september 1965. Selanjutnya setelah terjadinya pemberontakan PKI, istilah Pendidikan Kewarganegaraan atas usul Menteri Kehakiman waktu itu Mr. Suhardjo diubah menjadi “ Pendidikan 
Kewargaan Negara" dan berlaku sampai dengan tahun 1968. Diberlakukannya Kurikulum 1968 namanya berubah lagi menjadi "Pendidikan Kewarganegaraan”.

PKn menurut kurikulum 1968 berada dalam Kelompok Pembinaan Jiwa Pancasila baik di sekolah Dasar maupun di sekolah Menengah. Bedanya adalah di SD kelompok mata pelajaran terdiri dari Pendidikan agama, Pendidikan Kewarganegaraan, Bahasa Indonesia, Bahasa Daerah dan Olah Raga. Sedangkan di di SMA tanpa Bahasa daerah. Bahan-bahan pengajaran Pendidikan Kewarganegaraan menurut kurikulum 1968 tersebut digunakan sampai dengan ditetapkannya Pendidikan Kewarganegaraan dalam Kurikulum 1975 dengan nama "Pendidikan Moral Pancasila" (PMP) sebagai nama Bidang Studi (BS) untuk Pendidikan Kewarganegaraan yang tujuannya adalah untuk membentuk warganegara Pancasilais yang beriman dan bertaqwa kepada Tuhan Yang Maha Esa. Dengan ditetapkanya ketetapan MPR No. II/MPR/1978 tentang Pedoman Penghayatan dan Pengamalan Pancasila (P4) maka materi bidang studi PMP dilengkapi atau bahkan di dominasi oleh materi (P4) yang cenderung sebagai bahan indoktrinasi untuk pendidikan dan pelatihan warganegara.

Sebagaimana telah dikemukakan di atas PKn telah muncul dengan berbagai nama. Numan Somanteri (1972) mengemukakan bahwa istilah "Civics dan Civics Education" telah muncul masing-masing dengan nama:

a. Pendidikan Kewarganegaraan (1957);

b. Civics (1962);

c. Pendidikan Kewargaan Negara (1968).

Materi Pendidikan Kewarganegaraan yang muncul dengan berbagai nama tersebut antara lain Pendidikan Kewarganegaran (1957) membahas cara memperoleh dan kehilangan kewrganegaraan. Sedang Civics (1962) lebih banyak membahas tentang Sejarah Kebangkitan Nasional, UUD, Pidato-Pidato Politik Kenegaraan, yang terutama diarahkan untuk "nation and character building” bangsa Indonesia, seperti pada waktu pelaksanaan pelajaran Civics di Amerika Serikat pada tahun-tahun setelah Declaration of Independen.

Pidato-Pidato Politik Kenegaraan itu dikemas dengan nama "Tujuh Bahan Pokok Indoktrinasi” (TUBAPI) yang berisi pidato-pidato politik kenegaraan mantan Presiden Soekarno ditambah dengan Manifesto Politik (Manipol) dan Undang- 
Undang Dasar 45, Sosialisme Indonesia, Demokrasi dan Ekonomi Terpimpin, Kepribadian Indonesia (USDEK). Pada masa pemerintahan Orde Baru bahan-bahan pelajaran yang bersifat indoktrinasi tersebut dibuang dan dihilangkan sama sekali melalui Kurikulum 1968 dengan melakukan perubahan-perubahan materi dan metode penyampaian. Namun materi pelajaran atau kelompok mata pelajaran untuk Pendidikan Kewarganegaraan tersebut adalah Kelompok Pembinaan Jiwa Pancasila. Kelompok Pembinaan Jiwa Pancasila ialah Kelompok segi pendidikan yang terutama ditujukan kepada pembentukan mental dan moral Pancasila serta pengembangan manusia yang sehat dan kuat fisiknya dalam rangka pembinaan bangsa.

Sebagai alat formal dipergunakan 2 segi pendidikan: Pendidikan Agama, Pendidikan Kewargaan Negara, Pendidikan Bahasa Indonesia, Bahasa Daerah dan Olahraga. Pendidikan Agama diberikan secara intensif sejak dari kelas I sampai kelas VI dan diganti pendidikan budipekerti saja.

Begitu pula Pendidikan Kewargaan Negara, yang mencakup sejarah Indonesia, Ilmu Bumi dan Pengetahuan Kewargaan Negara, selama masa pendidikan yang enam tahun itu diberikan terus menerus. Sedangkan Bahasa Indonesia dalam kelompok ini mendapat tempat yang penting sekali, sebagai alat pembina cara berpikir dan kesadaran nasional. Sedangkan Bahasa Daerah digunakan sebagai langkah pertama bagi sekolah-sekolah yang menggunakan bahasa tersebut, sebagai pengantar sampai kelas III dalam membina jiwa dan moral Pancasila. Olahraga yang berfungsi sebagai pembentuk manusia Indonesia yang sehat rohani dan jasmaninya diberikan secara teratur semenjak anak-anak menduduki bangku sekolah.

Sama halnya Kurukulum Sekolah Dasar dan Sekolah Menengah Pertama 1968, Rencana Pendidikan dan Pelajaran SMA tahun 1968 juga dibagi kedalam tiga kelompok besar masing-masing Kelompok Pembina Jiwa Pancasila, Kelompok Pembina Pengetahuan Dasar, dan Kelompok Pembina Kecakapan Khusus. Pendidikan Kewargaan Negara termasuk dalam Kelompok Pembina Jiwa Pancasila bersama Pendidikan Agama, Bahasa Indonesia dan Pendidikan Olah Raga. Mata pelajaran Kewargaan Negara di SMA berintikan: (1) Pancasila dan UUD 1945; (2) Ketetapan-Ketetapam MPRS 1966; (3) Pengetahuan umum tentang PBB. 
Tujuan diajarkannya adalah agar tiap-tiap warganegara Indonesia berkewajiban mengamalkan Pancasila dan UUD 1945 serta merealisasikan isi dan jiwa UUD 1945 dan ketetapan-ketetapan MPRS sebagai ketentuan-ketentuan pelaksanaannya. Dengan demikian Kewargaan Negara tidak saja wajib dipelajari tetapi lebih-lebih lagi merupakan bentuk sikap hidup. Karena komunikasi modern yang mendekatkan bangsa yang satu dengan yng lainnya maka Indonesia yang tergabung dalam PBB berkewajiban menyelami dan mempelajari bentuk organisasi PBB itu. Salah satu hal penting dari kurikulum SMA 1968 tersebut adalah Mata Pelajaran Kewargaan Negara yang pengajarannya senantiasa dikorelasikan dengan pelajaran lain seperti sejarah Indonesia, Ilmu bumi Indonesia, Hak Asasi Manusia dan Ekonomi, sehingga mata pelajaran Kewargaan Negara tersebut menjadi lebih hidup dan lebih menantang serta lebih bermakna.

\section{Pendidikan Kewarganegaraan Pada Era Orde Baru}

Dalam perubahan kurikulum sekolah tahun 1968 menjadi kurukulum tahun 1975 mata pelajaran PKn atas dasar Keputusan MPR 1978 diganti dengan nama baru yang dikenal dengan Pendidikan Moral Pancasila (PMP). Ini merupakan hasil penggabungan mata pelajaran sejenis menjadi bidang studi. Bidang studi PMP merupakan bahan-bahan mata pelajaran yang menyangkut Pancasila dan UUD 1945 dipisahkan dari mata pelajaran yang bersangkut paut diantaranya mata pelajaran Sejarah, Ilmu Bumi dan Ekonomi. Sedangkan gabungan mata pelajaran Sejarah, Ilmu Bumi dan Ekonomi menjadi bidang studi Ilmu Pengetahuan Sosial (IPS) atau Studi Sosial (Social Studies) dan saat ini bernama Pendidikan Ilmu Pengetahuian Sosial (PIPS). Hal yang sama masih tetap berlaku saat berlakunya Kurikulum 1984 sebagai penyesuaian Kurikulum 1975. Mengenai bidang studi PMP tersebut Depdikbud telah mengeluarkan Penjelasan Ringkas tentang Pendidikan Moral Pancasila (Dikbud, 1982) di mana dikemukakan berbagai hal penting antara lain adalah sebagai berikut:

Pendidikan Moral Pancasila (PMP) secara konstitusional mulai dikenal dengan adanya TAP MPR No. IV/MPR/1973 tentang Garis-garis Besar Haluan Negara. Dengan adanya Ketetapan MPR No. II/MPR/1978 tentang Pedoman Penghayatan dan Pengamalan Pancasila (P4), maka materi PMP didasarkan pada isi 
P4 tersebut. Oleh karena TAP MPR No. II/MPR/1978 merupakan penuntun dan pegangan hidup bagi sikap dan tingkah laku setiap manusia Indonesia dalam kehidupan bermasyarakat serta bernegara, maka dijadikan sumber, dan tempat berpijak, isi, dan evaluasi PMP. Dengan demikian hakekat PMP tiada lain adalah pelaksanaan P4 melalui jalur pendidikan formal. Di samping pelaksanaan PMP di sekolah-sekolah di dalam masyarakat umum giat diadakan usaha pemasyarakatan P4 lewat berbagai penataran, dalam rangka menyesuaikan Kurikulum 1975 dengan P4 dan GBHN 1978 mengusahakan adanya buku pegangan bagi murid dan guru Sekolah Dasar, Sekolah Menengah Tingkat Pertama dan Sekolah Menengah Tingkat Atas. Usaha itu telah menghasilkan Buku Paket PMP.

Dari penjelasan ringkas di atas dapat disimpulkan bahwa (1) P4 merupakan sumber, dan tempat berpijak, isi, dan cara evaluasi PMP melalui pembakuan kurikulum1975; (2) dengan dihasilkannya Buku Paket PMP untuk semua tingkat pendidikan di sekolah maka Buku Pedoman Pendidikan Kewarganegaraan (Manusia dan Masyarakat Baru Indonesia, dinyatakan tidak berlaku lagi; dan (3) P4 tidak hanya diberlakukan untuk sekolah-sekolah tetapi juga untuk masyarakat pada umumnya melalui berbagai penataran Pedoman Penghayatan dan Pengamalan Pancasila (P4) oleh BP7, untuk sekolah diberlakukan bidang studi PMP sedangkan untuk masyarakat diberlakukan P4. Namun demikian materi PMP tersebut didominasi oleh bahan-bahan P4 yang disesuaikan dengan masing-masing lingkungan yaitu lingkungan sekolah dan lingkungan masyarakat.

Dalam perkembangan selanjutnya PMP karena berbagai perubahan dan berbagai pertimbangan, dengan disusunnya kurikulum sekolah tahun 1994 diubah menjadi Pendidikan Pancasila dan Kewarganegaraan (PPKn) yang terutama didasarkan pada UU Sistem Pendidikan Nasional No. 2 tahun 1989 ayat 2 yang menyatakan bahwa:

Isi kurukulum setiap jenis, jalur, dan jenjang pendidikan wajib memuat:

a. Pendidikan Pancasila;

b. Pendidikan Agama;

c. Pendidikan Kewarganegaraan.

Sebagai sekedar perbandingan dari sisi tujuan, dalam era pemerintahan Orde Baru, bidang studi PMP bertujuan untuk membentuk Manusia Pancasilais di mana 
menurut Kurikulum Sekolah Dasar 1975 tersebut seluruh bidang studi berperan untuk mencapai tujuan pendidikan tersebut di atas. Membentuk Manusia Pancasilais bukan hanya merupakan tanggung jawab bidang studi PMP semata. Oleh karena kurikulum 1984 merupakan penyempurnaan terhadap Kurikulum 1975, maka tujuan membentuk Manusia Indonesia Pancasilais tetap merupakan tema utamanya.

Sealama masa Orde Baru kurikulum telah berubah beberapa kali yang berakibat berubahnya pula kurikulum PKn yang diawali dengan kurikulum 1962 ke kurikulum tahun 1968, kemudian menjadi kurikulum tahun 1975, dan selanjutnya kurikulum tahun 1984 sebagai penyempurnaan terhadap kurikulum 1975, dan terakhir kurikulum tahun 1994 sebagai kelanjutan kurikulum tahun 1984. Perubahan PKn yang bernama Pendidikan Moral Pancasila (PMP) menjadi Pendidikan Pancasila dan Kewarganegaraan (PPKn) juga terjadi dalam era Orde Baru.

Kedua penggalan waktu yang berbeda jaman itu meiliki tujuan yang sama yaitu mendidik, membentuk, atau mempersiapkan warganegara yang baik menurut apa yang dianggap baik menurut pandangan rezim yang berkuasa pada masa itu. Penggalan waktu pertama Orde Lama menekankan pada "nation and character building" sedangkan periode berikutnya yaitu Orde Baru lebih menekankan pada "Pembangunan Manusia Indonesia Seutuhnya" yang masing-masing telah diketahui kekuatan dan kelemahan-kelemahannya. Yang pertama berakhir dengan lahirnya Gerakan 30 September PKI dan yang kedua berakhir dalam situasi pemerintahan yang korup, yang ditandai dengan banyaknya korupsi, kolusi, dan nepotisme (KKN) yang dibangun di atas legitimasi politik dengan nilai-nilai kultur feodalisme dan primordialisme. Selama masa Orde Baru materi PPKn didominasi oleh materi P4 menyebabkan pembelajaran PPKn di kelas berlangsung dengan sangat kaku tanpa improvisasi dan cenderung kearah indoktrinasi. Akibat lebih jauh adalah siswa lebih terbiasa menghafalkan nilai-nilai dan moral Pancasila dan bukannya mengamalkan nilai-nilai dan moral tersebut.

\section{Pendidikan Kewarganegaraan Pada Era Reformasi}

Bagaimana PKn di era Reformasi? Akankah pendekatan, cara-cara, proses dan prosedur yang telah ditempuh selama ini akan menjadi kelanjutan kedua episode kehidupan sosial dan politik masa lalu yang pada dasarnya bukan membahagiakan 
atau mensejahterakan rakyat namun justru sebaliknya. Akankah perjalanan kehidupan sosial dan politik bangsa ini dalam era Reformasi sekarang ini akan berakhir dengan tragis seperti masa lalu. Mampukah bangsa dan para pemimpin sosial politik serta tokoh masyarakat membawa bangsa ini kepada kehidupan yang lebih baik, lebih sejahtera, lebih aman, lebih bebas dalam menuju masyarakat madani Indonesia. Masyarakat yang beradab yang menjunjung tinggi nilai-nilai luhur yang menghargai harkat dan martabat manusia, seperti dicita-citakan. Semua itu akan sangat bergantung pada pilihan-pilihan kehidupan sosial politik dan kenegaraan yang ditentukan bersama sebagai manifestasi dari harapan, keinginan dan cita-cita baik sebagai individu, warga masyarakat dan warganegara.

Untuk mencapai masyarakat yang dicita-citakan itu peran pendidikan amat sentral. Mengingat peran pendidikan yang amat strategis dalam membawa bangsa ini menjadi bangsa yang maju, yang sejahtera dan diperhitungkan dalam percaturan internasional maka pendidikan haruslah pendidikan yang bebas dari berbagai kelemahan yang telah terjadi selama ini. Salah satu kelemahan yang mendasar adalah ketidakjelasan dan ketidakkonsistenan para pembuat kebijakan dan pelaksanaan sistem pendidikan (Senat IKIP Bandung, 1999). Demokratisasi bidang pendidikan amat diperlukan terutama dalam memposisikan warganegara sebagai subyek dan bukan sekedar obyek dari kepentingan politik penguasa semata. Demokratiosasi di bidang pendidikan yang ditindaklanjuti dengan pendidikan demokrasi adalah suatu yang memungkinkan upaya pengembangan segenap potensi individu warganegara Indonesia secara optimal sesuai dengan fitrah insaninya.

Guna memperoleh perbandingan, memperluas visi dan memberi dasar yang kokoh bagi pendidikan untuk warganegara demokratik "democratic citizenship" yang seharusnya menjadi dasar pendidikan Indonesia dalam era reformasi tersebut ada baiknya mengutip pendapat Thomas Jefferson sebagai penulis Deklarasi Kemerdekaan Amerika yang menyatakan bahwa: “...that the knowledge, skills and behaviors of democratic citizenship do not just occur natullay in oneself but rather they must be taught consciously through schooling to teach new generation, i.e they are learned behaviors". Agar peran pendidikan dipahami secara jelas dalam mendidik warganegara yang demokratis tersebut John F. Kennedy misalnya lebih memperkuat pendapat Jefferson dengan mengatakan bahwa: "There is an old saying 
that the course of civilization is a race between catastrophe and education. In a democracy such as ours, we must make sure that education wins the race".

Kedua pandangan tersebut memberi isyarat yang jelas bahwa pendidikan amat berperan dalam mendidik warganegara yang demokratis, yang menyiratkan dan mensyaratkan bahwa pendidikan itu sendiri haruslah demokratis dan dilakukan dengan cara-acara yang demokratis pula sebab pendidikan harus efektif yang didukung oleh faktor-faktor startegis lingkungan internal dan eksternal. Dalam konteks itu dapat diidentifikasikan parameter dan variabel yang signifikan, baik yang berhubungan dengan proses belajar mengajar, evaluasi, sistem kurikulum, sistem manajemen dan faktor kontekstual sosial, ekonomi, politik, hukum dll, yang dibangun oleh sumber daya manusia yang kompeten dan teruji. Jika pendidikan itu mau efektif, ia harus kuat, punya kemandirian, dan hubungan saling bantu dengan faktor eksternalnya dengan anggaran yang cukup untuk membiayai SDM. Pendidikan Kewarganegaraan yang efektif selain yang tersebut di atas, perlu visi yang dibangun bersama tentang warganegara yang baik, demokratis, cerdas, terampil dalam menuju masyarakat madani.

Keadaan masa lalu itu menunjukkan betapa rapuhnya pembangunan termasuk pembinaan warganegara yang hanya mengandalkan faktor keamanan, ekonomi atau teknologi belaka tanpa memikirkan secara sungguh sungguh individuindividu warganegara sebagai SDM yang akan terlibat dalam keseluruhan sistem yang dibentuk dengan berbagai pendekatan tersebut. Pendekatan-pendekatan yang dianut dalam pembangunan bangsa dan warganegara masa lalu itu secara nyata telah menunjukkan kegagalan-kegagalannya terutama bagi kemajuan dan perkembangan bangsa dalam menciptakan masyarakat yang damai, saling menghargai, memiliki sikap toleransi, demokratis, bertanggungjawab, berdisiplin, dan menghormati aturan-aturan serta hukum dan ketentuan-ketentuan yang berlaku. Keadaan seperti ini mendorong kita semua untuk memikirkan penataan kembali pendidikan bagi warganegara Indonesia khususnya PKn Indonesia.

Dengan mencermati ciri-ciri PKn dalam kedua kurun waktu di atas nampak bahwa baik substansi materi maupun metode mengajarnya tidak terlalu banyak mengalami perubahan, bahkan dapat dikatakan bahwa kelemahannya justru terletak pada ketidakkonsistenan dalam melaksanakan apa yang ditetapkan oleh kurikulum. 
Terlalu banyak penyimpangan yang terjadi sehingga sulit untuk dapat memastikan kelemahan-kelemahan pengajaran PKn yang terjadi. Bahkan kalau mau lebih obyektif dapat dikatakan bahwa mata pelajaran PKn menurut kurikulum 1968 jika dilaksanakan dengan baik akan mampu menyiapkan warganegara yang baik Mengapa?, karena selain mempelajari mata pelajaran PKn murid-murid juga mempelajari Pendidikan Agama, mereka juga mempelajari Bahasa Indonesia dan Olah Raga sehingga dapat dihasilkan manusia Indonesia seutuhnya sebagaimana juga telah dicanangkan oleh Orde Baru yaitu manusia yang sehat rokhani dan jasmaninya, sebagaimana juga dicanangkan dalam kurikulum-kurikulum selanjutnya.

Telah diuraikan tedahulu bahwa ketiga rezim pemerintahan memiliki perhatian yang begitu signifikan terhadap PKn. Hal itu dapat dilihat dari berbagi kebijakan pendidikan khususnya tentang Pendidikan Kewarganegaraan yang seolaholah amat dipengaruhi oleh perubahan-perubahan situasi politik dan kenegaraan. Pada masa-masa yang lalu yang jika tujuannya dicermati senantiasa menempatkan PKn tersebut sebagai "alat politik" bukan sebagai "alat pendidikan politik" yang didasari oleh nilai-nilai demokrasi tetapi justru untuk mengarahkan dan mendominasi nilai-nilai yang memungkinkan sebuah rezim untuk mempertahankan "kemapanan” yang mendukung kekuasaan yang ada.

Perubahan-perubahan tersebut terjadi karena adanya perubahan dalam sistem sosial politik, dan kenegaraan yang memang semakin menuntut pada kemantapan dalam PKn untuk menjamin kelangsungan hidup Negara Kesatuan Republik Indonesia (NKRI). Adanya tuntutan-tuntutan perubahan kearah kehidupan yang lebih demokratis harus diakui sebagai hasil positif dari pendidikan PKn belakangan ini termasuk ekses yang sekaligus merupakan tantangan bagi proses demokratisasi itu sendiri.

Tuntutan perubahan itu selain disebabkan oleh hal-hal di atas juga karena beberapa sebab lain yang amat fundamental seperti dikemukakan oleh Aziz Wahab (1998) dengan mengatakan bahwa: Bidang Studi PKn sesuai fungsi dan tujuannya selama ini menjadi sarana untuk membina warganegara untuk lebih mengetahui hak dan kewajibannya dalam kehidupan berbangsa dan bernegara. Namun sejalan dengan terjadinya reformasi diperlukan kajian ulang terhadap relevansi meteri PKn 
dalam kurikulum karena beberapa alasan, di antaranya: (1) Selama Orde Baru yang lalu ada kekacauan pengertian antara negara dan pemerintah /rezim yang berkuasa; seakan-akan keduanya menjadi identik. Hal itu mengakibatkan penerjemahan PKn ke dalam kurikulum pun banyak diwarnai oleh perspektif dan kepentingan pemerintah dengan mengatasnamakan perspektif dan kepentingan negara. Hal yang sama sesungguhnya bukan hanya berlaku untuk PKn tetapi juga untuk bidangbidang studi lainnya seperti Sejarah, Ekonomi, dan Geografi. (2) Karena alasan pertama di atas, topik-topik tertentu lebih banyak diangkat (misalnya soal kepatuhan, kesetiaan pada pemerintah yang berkuasa, keamanan nasional) yang bertujuan menguatkan kedudukan pemerintah yang berkuasa; sedangkan topik-topik lain seperti hak asasi manusia, demokrasi politik, demokrasi ekonomi, hak-hak rakyat, kewajiban pemerintah kepada publik, kebebasan menyatakan pendapat, kebebasan beragama, kurang ditampilkan secara proporsional. (3) PKn adalah sarana pendidikan politik bangsa. Namun pendidikan politik yang dimaksud selama ini cenderung "sepihak" dan "menolog", yaitu mendukung kelanggengan kekuasaan Orde yang berkuasa. Akibatnya siswa tidak disiapkan untuk berpikir secara dewasa, bertanggung jawab dan jujur bahkan terhadap dirinya sendiri. Produk akhirnya adalah peserta didik yang "tanpa pilihan", harus menerima apa adanya tanpa dapat dan mampu mempertanyakan hal-hal di luar koridor yang telah ditentukan sebelumnya. Dari sudut perkembangan moral, hal ini tidak menguntungkan karena membuat siswa menjadi kerdil dalam berpikir. PKn lebih menekankan segi "to tell students about what are desiable behaviors" dan bukan "to ask and let student to think and to find...". (4) Dalam kenyataan, terjadi berbagai kebingungan peserta didik akibat apa yang diajarkan di sekolah berbeda kenyataannya. Akibat lanjutnya adalah secara tidak disadari kita menyiapkan generasi yang memiliki kepribadian terpecah.

Berdasarkan alasan-alasan di atas, kaji ulang dan peninjauan kembali terhadap materi dan metodologi PKn dalam kurikulum 1994 merupakan suatu keharusan dalam Era Reformasi sekarang ini. Kaji ulang diarahkan terhadap hal-hal berikut ini:

1. Sejauh manakah materi yang ada dalam kurikulum masih relevan dengan semangat bangsa kita yang dengan memanfaatkan momentum reformasi 
sedang memformulasikan kembali format dan implementasi nilai-nilai Pancasila dalam kehidupan berbangsa dan bernegara. Acuan kita adalah kehidupan berbangsa dan masyarakat Indonesia di masa depan, berdasarkan pengalaman di masa lalu dan sekarang.

2. Banyak keluhan selama ini tentang padat dan banyaknya materi yang mesti dipelajari oleh siswa. Hal inipun perlu dikaji ulang, materi manakah yang dapat dikeluarkan, digabungkan, dirampingkan, dan meteri mana yang benar-benar esensial bagi anak, masyarakat dan kehidupan bangsa.

3. Dari segi metodologi, metode yang cenderung doktriner dan monolog selama ini, perlu ditinjau ulang dari segi karakter belajar dan tahap-tahap perkembangan peserta didik. Sudah cukup lama kita mengetahui bahwa PKn adalah pelajaran yang "membosankan" bahkan cenderung "tidak disukai" siswa karena materi dan metodenya memang tidak menantang siswa secara intelektual, di samping amat sarat dengan pesan-pesan ideologis rezim yang berkuasa.

Proses perubahan kearah demokratisasi dan pendewasaan sebagai bangsa yang berdaulat yang memiliki kepercayaan dan jati diri sebagai bangsa masih harus dibenahi melalui pengembangan konsep "baru" PKn melalui kurikulum sekolah untuk masa-masa yang akan datang. Satu hal yang amat mengkhawatirkan dalam proses penyiapan warganegara yang demokratis itu adalah kurang diperhatikannya unsur hukum dalam kurikulum PKn padahal warganegara yang demokratis itu harus memiliki disiplin dan tanggung jawab. Selain disiplin dan tanggung jawab warganegara demokratis juga harus memiliki komitmen yang tinggi terhadap kemajuan dan kesejahteraan masyarakat. Namun harus disadari bahwa hal itu hanya mungkin dicapai dengan menumbuhkan pemahaman dan pengamalan tentang kepatuhan terhadap aturan dan nilai-nilai hukum yang berlaku. Untuk itu pengajaran hukum yang secara langsung berkaitan dengan kehidupan anak sehari-hari, di dalam lingkungan keluarga, lingkungan bermain, lingkungan sekolah dan masyarakat secara keseluruhan harus menjadi perhatian yang serius dalam pengembangan kurikulum untuk pendidikan warganegara baik melalui bidang studi Pendidikan IPS ataupun melalui PKn itu sendiri. 
Dalam era reformasi dan dalam kehidupan demokrasi setiap orang sebagai warganegara memperoleh kebebasan dan diperlakukan secara adil. Untuk itu setiap warganegara harus memperoleh kesempatan yang sama untuk memperoleh pendidikan yang baik. Dalam pendewasaan dan sikap keterbukaan dan kebebasan itu baik politik maupun ekonomi itu harus dijelaskan secara tuntas bahwa: dasardasar demokrasi itu sebagaimana dikemukakan oleh Chapin dan Messsick (1989:114) diantaranya adalah seperti berikut: "Each person has one vote; Citizens have equal protection under the law; Decuisions and laws can be reviewed and amended by lawful process; Decisions and government acts are based on law”.

Tujuannya adalah agar setiap warganegara menjadi cerdas, dapat berpikir kritis dan kreatif serta memiliki sikap disiplin pribadi dan dapat berpartisipasi dalam mengatasi berbagai persoalan baik pribadi, maupun masyarakat lingkungannya. Lahirnya warganegara seperti itu menuntut perubahan-perubahan mendasar dalam pendidikan pada umumnya dan pendidikan kewarganegaraan khususnya.

\section{Penutup}

Uraian di atas telah membawa dan mengantarkan Bangsa Indonesia kepada situasi yang mendorong bangsa ini untuk tidak mengulangi langkah-langkah politik yang keliru yang cenderung lebih menekankan kepada kekuasaan dengan menomorduakan rakyat dan masyarakat dalam sistem kehidupan berbangsa dan bernegara. Pengakuan terhadap hak-hak individu yang didasari rasa tanggung jawab harus ditambahkan, penghargaan dan penghormatan terhadap hak-hak dasar manusia serta lebih menekan lagi pada kemajuan dan kesejahteraan rakyat harus sudah mulai menjadi dasar-dasar kebijakan nasional dengan senantiasa membuka diri terhadap perubahan global dan dengan respon yang dilakukan secara cerdas. Semua itu hanya mungkin dapat dicapai jika dilakukan perubahan paradigma terhadap PKn. Paradigma baru tersebut menuntut diakukannya redifinisi dan revitalisasi implementasi konsep PKn sehingga benar-benar menjadi sebuah wadah yang dapat membangun dan mengembangkan berbagai kemampuan warganegara agar dapat lebih sensitif, proaktif, inovatif, dan kreatif, serta cerdas sehingga dapat berpartisipasi secara aktif dan efektif dalam kehidupannya sebagai warganegara dan warga masyarakat. 
Redifinisi dan revitalisasi pengertian serta tujuan PKn akan mendorong lahirnya paradigma baru PKn tersebut. Paradigma baru tersebut harus disusun di atas pilar-pilar demokrasi yang akan mendukung nuansa demokratis yang saat ini telah berkembang di masyarakat. Atas dasar beberapa konsep dimaksud akan mendasari paradigma baru PKn Indonesia sebagai berikut:

1. Konstitusionalisme;

2. Percaya kepada Tuhan Yang Maha Esa;

3. Warganegara yang cerdas;

4. Kedaulatan perorangan (people souvereignity);

5. Pers yang bebas;

6. Kekuasaan UU (the rule of law);

7. Hak-hak dasar manusia;

8. Pembagian kekuasaan (division of power);

9. Sistem pengadilan yang bebas (independent yudicial system);

10. Desentralisasi (decentralization /local autonomy);

11. Kesejahteraan sosial dan keadilan sosial (social welfare and social justice);

12. Patriotisme dan nasionalisme (patriotism and nationalism).

Paradigma baru PKn tersebut menuntut adanya perubahan dalam seluruh aspek pembelajaran PKn dimulai dari tujuan sampai pada pengembangan bahan ajar, metode mengajar dan penilaiannya. Dari sisi tujuan misalnya yang umunya diketahui dari berbagai literatur bahwa tujuan PKn adalah untuk membentuk warganegara yang baik. Yaitu warganegara yang mampu melaksanakan hak-hak dan kewajiban-kewajibannya.

\section{Daftar Pustaka}

Abdul Azis Wahab, (1998) Kajian Terhadap Kinerja Kurikulum 1994 dan FaktorFaktor yang Mempengaruhi. Bandung: Jurusan PPKN IKIP Bandung.

Azyumardi Azra. (2006). Paradigma Baru Pendidikan Nasional. Penerbit Buku Kompas,

Jakarta. 
Depdikbud, (1993) Kurikulum Pendidikan Dasar dan Menengah. GBPP PKn.

Depdikbud, (1968) Kurikulum Pendidikan Dasar dan Menengah. GBPP PKn.

Depdikbud, (1982) Penjelasan Ringkas Tentang Buku PMP. Dirjend Dasmen..

Muchson AR. (2004). Pendidikan Kewarganegaraan Paradigma Baru (Jurnal Civics)

vol. 1, No. 1 Juni 2004.

Numan Somantri. (1972) Beberapa Masalah dalam Pengajaran PKn, seminar Nasional Civic, Surakarta: Tawangmangu.

Print, Murray et al. (1999). Civic Education for Civil Society. London: Asian Academic

Press.

Redaksi Sketsa Masa. (1961). Tujuh Bahan Pokok Indoktrinasi. Surabaya: Penerbit GRIP.

Suryadi, Ace dan Somantri. (2000). "Pemikiran Ke Arah Rakayasa Kurikulum Pendidikan Kewarganegaraan" Paper, The International Seminar: The Need for

New Indonesian Civic Education, March 29, 2000, at Bandung.

Supardo dkk. (1962) Manusia dan Masyarakat Baru Indonesia. Jakarta: Balai Pustaka.

Waterwoth, Peter. (1998). "Trends in Social Studies Education and Citizenship Education”. Paper. Faculty of Education, Deakin University, Australia. 